\title{
Trends in entrepreneurial behaviour among immigrant students: Conclusions from research conducted at the University of Social Sciences
}

\author{
Paulina Kramarz, Maciej Dębski, Lidia Luty
}

\section{A B S T R A C T}

Objective: The main aims of the thesis were to compare entrepreneurial behaviour trends in a group of Polish and foreign students and an attempt to define the determinants of such behaviours.

Research Design \& Methods: Research was conducted using a questionnaire. Descriptive statistics methods were also used.

Findings: The undertaken research shows the diversity of entrepreneurial behaviours among both Polish and foreign students surveyed. Foreign students participating in the study showed a greater propensity to take risks and greater flexibility in their business plans, which may be indicative of greater skills and ability in adapting to the requirements of the labor market.

Contribution \& Value Added: In the light of the undertaken research, it can be assumed that the state of the education system may account for one of the most important factors in facilitating change of the growing labor supply into benefits in the form of economic recovery and the creation of employment opportunities.

\begin{tabular}{ll}
\hline Article type: & research paper \\
Keywords: & Immigrants; students; Entrepreneurship; entrepreneurial behav- \\
JEL codes: & iour; business barriers \\
\hline
\end{tabular}

\section{Suggested citation:}

Kramarz, P., Dębski, M., \& Luty, L. (2019). Trends in entrepreneurial behaviour among immigrant students: Conclusions from research conducted at the University of Social Sciences. International Entrepreneurship Review (previously published as International Entrepreneurship / Przedsiębiorczość Międzynarodowa), 5(4), 25-39. https://doi.org/10.15678/IER.2019.0504.02

\section{INTRODUCTION}

The number of students in Poland decreases year by year. During the years 2013-2017, this decrease fell to $16.7 \%$, which meant a reduction in the number of students by 258.5 thousand people. A similar trend covered all Polish voivodships, being the weakest in the Mazowieckie 
Voivodship, where there was a $12 \%$ drop in the number of students. In Warsaw city it was even smaller - less than $10 \%$. Mazowieckie Voivodship is a region of one-fifth of all Polish students. A total of 230.3 thousand people studied at Warsaw universities in 2017, which constituted $17.85 \%$ of all students nationvide. The Mazowieckie Voivodship was also the region with the most rapid increase in the percentage of immigrant students. During the years 2013-2017, it increased from 3.8\% to 9.0\% (Główny Urząd Statystyczny [GUS], 2019).

The intensified influx of foreign students into the Mazowieckie Voivodship was accompanied by a positive balance of foreign migrations for permanent residence of the working age population. This is an exceptional situation when compared to the country in which it remains at a negative level - in 2016 and 2017 it had declined to $-0.15 \%$ o (GUS, 2019).

The Mazowieckie Voivodship has the largest number of enterprises and entrepreneurs operating in the country. The number of enterprises in this region also increased at the quickest pace in the country - from 2013 to 2017 the number of registered enterprises increased by 84,372 units, and in Warsaw alone by 63,200 units. In the whole Mazowieckie Voivodship there were $18.78 \%$ of all Polish enterprises and in 2017, more than half of enterprises from the Mazowieckie Voivodship were located in Warsaw - 434676 business units from 809369 located in the Mazowieckie Voivodship (GUS, 2019). In connection with the above statements, one can ask the question about the role of immigrant students in shaping economic development and entrepreneurship in the region, which shows its huge potential, but also is already highly saturated with economic units of various sizes and profiles. At the same time, the increasing influx of working-age people from abroad increases the phenomenon of competition between entrepreneurs and people looking for employment. It seems important to conduct research on how competition in the Masovian labor market affects the educational aspirations of immigrant students and plans related to their undertaking the socalled entrepreneurial behavior. The purpose of this study was to attempt to define behavior trends related to the entry of foreign students to the labor market and the differences in entrepreneurial behavior undertaken by immigrant and domestic students.

\section{MATERIAL AND METHODS}

In the implementation of the research objective, two research hypotheses were formulated:

H1: Immigrant students are more likely to undertake entrepreneurial activities than host country students.

H2: Factors differentiating entrepreneurial attitudes of immigrant students and students of the host country include differences in educational motivations and a different attitude to risk.

The conducted analyzes used statistical data collected by Statistics Poland. The article presents the conclusions of the research conducted in 2018. The survey included 988 fully completed surveys collected from students of the University of Social Sciences. Foreign students constituted $28 \%$ of the total number of respondents. Among them, the dominant group were students from Ukraine $-93.43 \%$. Belarusians and Vietnamese were among the remaining national groups. The questions concerned respondents' plans to start a business, factors influencing this decision and educational needs corresponding to its launch. Descriptive statistics methods were used to analyze the material collected through the 
questionnaires. Verification and supplementation of pre-received applications was possible by using the chi square test of independence.

\section{LITERATURE REVIEW}

Nowadays, the dominant belief is that the entrepreneurship of immigrants, especially selfemployment is conducive to improving the condition of the economies of the receiving countries (Kubiciel-Lodzińska, Maj, Bębenek, 2018; Kuciński, 2004). However, one should remember that immigrant entrepreneurship is distinguished by a different specificity. This is the result of overlapping entrepreneurial cultures and standards of conduct from the country of origin on the established system in the receiving country (Glinka, 2018). Secondly, the fact of taking the risk of entering the foreign country's labor market and of changing the country of residence allows us to define the profile of immigrants as individuals willing to undertake activities with a higher degree of risk and in possession of characteristics of entrepreneurial behavior already at the moment of migration (Kosała, 2016). However, the pursuit of business activity in the case of immigrants does not always have to result from economic or ambition-based reasons. The reason for setting up an enterprise is often "forced entrepreneurship" - for example, the in connection with the difficulty of meeting the employers' requirements (Kosała, 2016). Another reason may be the perception of the potential resulting from the origin, which is conducive to undertaking activities such as teaching foreign languages, preparing language translations, employment mediation for immigrants (Andrejuk, 2016). At the same time, it is observed that immigrant entrepreneurship presents an opportunity to enjoy economic integration (Brzozowski, 2017).

In a general look at the fact of the inflow of foreigners, as a positive result of this phenomenon for the socio-economic development of regions, Kuciński (2014) lists taking over job positions that are not attractive to local people and the diversity of wages for work performed by people with higher and lower qualifications - as a result, it leads to raising the qualifications of the local population and thereby increasing their income. According to Kosała (2016), immigrants can often bring to the regions a resource in the form of rare qualifications. A similar effect may appear as a result of starting a business activity. Hence, long forgotten areas of activity (for example those due to low profitability) may be revived. In addition, the inflow of migrants may result in the stimulation of economic relations between countries (Glinka, 2018, Li, Isidor, Dau, \& Kabst, 2018), and according to Coleman, help to solve the problem of structural mismatch between labor demand and labor supply (Coleman, 1992 as cited in Kubiciel-Lodzińska, 2018, p. 11). Due to barriers to employment and self-employment by immigrants, it is not possible to replace the receiving country's workforce with one-to-one relationships. Undertaken entrepreneurial activities are rather complementary to the existing ones (Kuciński, 2014). Among the barriers to expansion into the labor market and the development of own businesses by immigrants, which ensure the occurrence of the effect described above Andrejuk (2016) and (Chen, Tajeddini, Ratten, \& Tabari, 2019), distinguishes among others the language barrier, amounts of taxes, problems with understanding the complexity of the law, high costs of running a business and the often reccurring expectation that immigrants will expect lower wages than the local population for their work. Studies show that migrants from non-western countries are in a less -advantageous position in the labor market than the locals (Storen, 2004). 
Research on entrepreneurship of immigrants most often refers to cultural and ethnic issues. Differences in the behavior of migrants from the same country seem to depend from the host country (Baltaci, 2017). To a lesser extent - although the need to undertake such research in trends is increasingly recognized - it concerns entrepreneurship undertaken by immigrant students (Glinka, 2018). Research conducted in the US by Hunt in 2011 and 2015 showed that the tendency to set up own businesses (research related to companies employing more than 10 people) was greater among immigrants than US citizens. Such a tendency was mainly true of immigrants being US-college graduates. In addition, the probability of establishing a company turned out to be greater in the group of immigrants for whom the reason for changing their place of residence was education or willingness to improve their financial situation (S. P. Kerr \& W. R. Kerr, 2016). On the other hand, the risk connected to migration may have a negative influence on the perception of the chances for business success. (Kushnirovich, Heilbrunn, \& Davidovich, 2018). Similarly, Kosała (2016) cites data from which it follows that Poland is a country in which economic activity is greater among migrants than indigenous inhabitants. The report prepared by OECD in 2010 indicates that $11.2 \%$ of Poles and $29.2 \%$ of immigrants were self-employed (Kosała, 2016). According to Kubiciel-Lodzińska (2018), groups of immigrants that can become entrepreneurs are permanent immigrants whose purpose for moving is paid activity or education - gaining financial resources is particularly important for this group, especially when they come from less developed countries than the receiving country. In the literature it is often stressed that migrants are more enterprising than natives (Kahn, La Martina, \& MacGarvie, 2017). However, it is also argued that migrants educated in their native country tend to be more enterprising than the natives educated in the host country (Blume-Kohout, 2016).

Also students are the subject of studies (Iwu, Ezeuduji, Eresia-Eke, \& Tengeh, 2016). Due to the fact that students of Ukrainian descent are usually the largest group among foreigners at Polish universities, this ethnic group is one of the most frequent reference points in the study of students immigrating to Poland. On the basis of the studies carried out among students from Ukraine, Andrejuk and Korniychuk (2018) state that among immigrant students, adaptation to the labor market starts at the beginning of education. Moving to self-employment takes place in accordance with three possible scenarios. Firstly, as undertaking business activity resulting from previously undertaken employment - the business profile is most often not related to the field of study, while cultural assimilation is high. Secondly, as starting a professional development in the direction of education - often in connection with a family business already operating. The third option is to take up self-employment after gaining a full qualification (graduation) - characteristic accompanying scholarship support or a course of study requiring a lot of time commitment (Andrejuk \& Korniychuk, 2018). The willingness to undertake gainful activity from the first moments of study is confirmed by studies conducted by Majkut, Pluta, Rybczyński (2016) at the WSB University in Wroclaw, according to which about $51.5 \%$ of immigrant students gain financial independence after 2 years of residence in Poland.

In connection with the demographic decline in Poland, and at the same time the opening of Polish universities to the possibility of educating foreign students, the number of immigrant students is growing year by year. Not without significance is the fact that foreign students can now apply for longer residence permits while studying. It also gives 
greater opportunities to take up employment (Kaczmarczyk, 2013). Therefore, the current research seems to be up-to-date due to the need to monitor the effects of the migration trends on the Polish economy. It is also a challenge for universities whose task is to adapt foreign graduates to the Polish labor market in the best possible way. More specifically according to the results of surveys carried out by Trzciński (2015) in the Mazowieckie, Małopolskie, Dolnośląskie and Lubelskie Voivodships, $64 \%$ of immigrant students wanted to remain in Poland after graduation. Particular attention that their education deserves, should also arise from the fact that often the immediate motivation for staying in Poland is the economic and political instability of the former Soviet republics, which in Poland's case are the place of origin of the dominant group of immigrant students (Andrejuk, 2016).

The subject of entrepreneurship of migrants, including students, does receive considerable attention and a growing interest in the topic can be observed, (Cruickshank \& Dupuis 2015) whilst being analyzed from various perspectives. However, the phenomenon is of a dynamic nature and requires further studies broadening our existing knowledge of the subject.

\section{RESULTS AND DISCUSSION}

\section{The tendency to start a business among domestic and foreign students}

In order to achieve the research goal, lists of results collected from groups of students with different characteristics regarding preferences and plans for conducting business activity and related experiments were used. The results obtained from students of Polish and foreign origin were compared. First, respondents were asked to provide information on their entrepreneurial plans. The results are presented in Table 1.

Table 1. Intention to start a business - answers given in the survey among the respondents in total and in the group of persons with and without experience in running a business activity

\begin{tabular}{|c|c|c|c|}
\hline \multirow{2}{*}{\multicolumn{2}{|c|}{$\begin{array}{l}\text { Intention to start a business - } \\
\text { total percentage of responses } \\
\text { in the group of respondents [\%] }\end{array}$}} & \multicolumn{2}{|c|}{ Including among people: } \\
\hline & & $\begin{array}{l}\text { Having experience } \\
\text { in running a business }\end{array}$ & \multirow[t]{2}{*}{$\begin{array}{l}\text { Without experience } \\
\text { in running a business }\end{array}$} \\
\hline \multicolumn{3}{|r|}{ Polish students } & \\
\hline Definitely yes & 8.68 & 38.36 & 5.30 \\
\hline Rather yes & 10.23 & 10.96 & 10.14 \\
\hline Considering & 38.38 & 17.81 & 40.72 \\
\hline Rather no & 26.75 & 12.33 & 28.40 \\
\hline Definitely no & 6.02 & 12.33 & 5.30 \\
\hline I do not know & 9.94 & 8.21 & 10.14 \\
\hline \multicolumn{4}{|c|}{ Foreign students } \\
\hline Definitely yes & 21.90 & 38.33 & 17.29 \\
\hline Rather yes & 34.31 & 40.00 & 32.71 \\
\hline Considering & 28.10 & 8.33 & 33.64 \\
\hline Rather no & 7.66 & 8.33 & 7.48 \\
\hline Definitely no & 0.36 & 1.66 & 0.00 \\
\hline I do not know & 7.67 & 3.35 & 8.88 \\
\hline
\end{tabular}

Source: own study. 
Among students of Polish descent, a group of people considering conducting business activity, but are still undecided, dominated with a figure of $38.38 \%$. Among the students declaring their intention to run a business, there were $8.68 \%$ of respondents expressing such intention in a decisive way and $10.23 \%$ of respondents rather inclined to start a business.

Respondents not planning to conduct business constituted $32.75 \%$ of all respondents (responses 'rather not' and 'definitely not' combined). They constituted a larger group compared to the group of people showing the intention to run their own business. An analysis of the responses of foreign respondents has highlighted some differences in intentions in this area. Over half of foreign respondents answered 'definitely yes' or 'rather yes'. Of this, $21.90 \%$ were definitely willing to start their own business. About $28.10 \%$ of respondents considered such a possibility. Due to the fact that the research group included both persons with and without experience in running a business, it was verified how it could influence the decision to resume this type of undertaking. Among students of Polish nationality, $10.23 \%$ of respondents had experience in running a business, while among foreign students it was twice as high (21.90\%). Among the respondents who already have experience in running a business, the percentage of people decisively setting up their own business was similar in both groups. It was just over $38 \%$ among Polish and foreign students. After considering people who were rather determined to run their own business, the difference became apparent. Altogether $49.32 \%$ among Polish students and $78.33 \%$ among foreign students expressing their intention to start business (in a more or less decisive way). Polish respondents with experience in running enterprise and not planning to create enterprise accounted for $24.66 \%$. Half of them (12.33\% of Polish respondents) was definitely not inclined to run a business. On the other hand, $9.99 \%$ of foreign students with business experience, did not plan to take up business again. In the case of the group of Polish origin, the percentage of those considering but undecided to start their own business was larger. Compared to the total number of Polish students surveyed, in the group of people having experience in running their own enterprise, both the percentage of respondents decided to establish an enterprise and those who decidedly do not intend to undertake such type of economic activity increased. Among foreign respondents, the percentage of people definitely not intending to run a business remained almost unchanged and stood at $1.66 \%$. Intentions related to economic activity represented by groups of respondents from Poland and abroad in both cases were closer to those observed in the total surveyed group than in the group of people with experience as an entrepreneur. Among Polish students, only $5.4 \%$ of people were fully decided to conduct business - less than in the case of the surveyed group in general. Exactly the same percentage of respondents definitely did not intend to run their own enterprise - so, less than in the case of the surveyed group in general and significantly less than in the case of a group of people with experience in running an enterprise. It is interesting that among respondents from abroad not conducting their own economic activity so far, no one expressed a clear lack of intention to start one The percentage of people planning such an undertaking was high and constituted $50 \%$ of the respondents. These results seem to confirm the conclusions cited in the literature about the greater willingness of immigrant students to start their own business. At the same time, it is interesting to note that a larger percentage of respondents who have experience as an entrepreneur express a tendency to lead it again than in the case of Poles. Having such experience, however, causes a certain approximation of tendencies in both national groups - the difference in the percentage of 
people expressing their intention to do business in both groups is narrowing. Having experience also favors the crystallization of further intentions.

Some respondents could indirectly draw conclusions about the benefits and risks of running their own business based on family experiences. In $74.37 \%$ of cases, Polish students subjected to the survey have the owner of the enterprise among their closest persons (Table 2 ).

Table 2. Intention to start a business - answers given in the survey among the respondents having the owner of the enterprise among their closest persons

\begin{tabular}{|l|r|r|}
\hline \multirow{2}{*}{\begin{tabular}{c} 
Intention to start a business - $\begin{array}{c}\text { 1 } \\
\text { possible responses }\end{array}$ \\
\cline { 2 - 3 }
\end{tabular}} & \multicolumn{2}{|c|}{ The percentage of responses in the group of respondents } \\
\hline Definitely yes & 9.98 & \multicolumn{1}{c|}{ Foreign students } \\
\hline Rather yes & 11.84 & 25.00 \\
\hline Considering & 38.04 & 38.50 \\
\hline Rather no & 23.54 & 23.50 \\
\hline Definitely no & 5.84 & 7.50 \\
\hline I do not know & 10.76 & 0.00 \\
\hline
\end{tabular}

Source: own study.

In the case of foreign students, this percentage was very similar and stood at $72.89 \%$. However, again there were some differences between the group of native and foreign students. The similarity connecting both groups was a visible, slightly greater propensity to undertake business activity by these people. It was declared with less determination than in the case of people who have their own experience of running a business, while the positive effect of observing the experience of family members on the decision to establish a business can be seen. In the case of Polish students, the percentage of respondents intending to run a business in this group was higher compared to the total number of respondents). Among the foreign respondents, the change was significantly more visible. The percentage of people declaring their willingness to conduct business activity answering 'definitely yes' and 'rather yes' was a total of 7.29 percentage points higher in the case of people observing entrepreneurial experience among relatives than in the group of foreign students in general. In this group of foreign students, none of the respondents stated that they definitely do not intend to run a business. It can therefore be said that the conclusions drawn from observing family experiences are conducive to the development of entrepreneurial attitudes, especially among the students surveyed from abroad. This possibility also facilitates making decisions about such plans - among foreign students, the percentage of people undecided about opinions about the possibility of starting a business was twice lower than among Polish students. In addition, among Polish students with family experience it was greater than in the total surveyed.

\section{Business start barriers and financial factor}

Often, the deciding factor if the intentions of running an own business can be fulfilled, is the wealth of financial resources or the possibility of obtaining them. Financial issues play an important role in making decisions related to making plans to start an own business, but this is not a decisive factor. This issue is developed slightly by the results obtained in relation to the question addressed to respondents about the reasons for refraining from 
starting a business (Table 3). A very common reason for not starting a business was the lack of funds. Most often it was a matter of concern to only those considering starting a business $-39.78 \%$ among Poles and more, as much as $61.04 \%$ among foreigners. Foreigners taking part in the survey more often than Poles pointed to the lack of financial resources as a reason to suspend starting a business, while they are determined to take such a step. The financial barrier was most often indicated in the groups of respondents declaring their intention to run a business as the answer 'definitely yes', 'rather yes, 'I am considering'. Secondly, insufficient knowledge was pointed out - in the case of people definitely planning to start their own enterprise, it was much more common among foreign students. Polish respondents most often indicated insufficient knowledge needed to conduct business activity being 'rather' determined to undertake it. The fear of the risk arising from developing their own business was more frequently indicated by Polish respondents. Among them, this barrier and lack of idea were most often mentioned by people who did not show willingness to start a business. The financial barrier prevailed among the undecided respondents. In the case of foreign respondents it was slightly different. Lack of an idea was the most common barrier for the undecided, the financial barrier was still of great importance, even in the case of people who were not inclined to play the role of an entrepreneur. A higher percentage of responses related to the inability to define the reason for not taking steps to implement finalized business plans was on the side of respondents of Polish origin $-17.74 \%$, while on the side of foreign respondents it was $10.00 \%$.

Table 3. Reasons for refraining from starting a business in groups of respondents with different attitudes to running a business - the percentage of responses

\begin{tabular}{|c|c|c|c|c|c|c|}
\hline \multirow{2}{*}{$\begin{array}{l}\text { Reasons for refraining from } \\
\text { starting a business }\end{array}$} & \multicolumn{6}{|c|}{ Intention to start a business - percentage of responses [\%] } \\
\hline & $\begin{array}{l}\text { Definitely } \\
\text { yes }\end{array}$ & $\begin{array}{c}\text { Rather } \\
\text { yes }\end{array}$ & $\begin{array}{c}\text { Consid- } \\
\text { ering }\end{array}$ & $\begin{array}{c}\text { Rather } \\
\text { no }\end{array}$ & $\begin{array}{c}\text { Definitely } \\
\text { no }\end{array}$ & $\begin{array}{l}\text { I do not } \\
\text { know }\end{array}$ \\
\hline \multicolumn{7}{|c|}{ Polish students } \\
\hline Lack of financial resources & 37.10 & 34.25 & 39.78 & 16.23 & 2.33 & 32.39 \\
\hline Insufficient Knowledge & 17.74 & 36.99 & 20.80 & 9.95 & 11.63 & 16.90 \\
\hline Fear of risk & 14.52 & 20.55 & 18.71 & 21.99 & 2.33 & 15.49 \\
\hline No consent from family members & 1.61 & 0.00 & 0.73 & 0.52 & 6.98 & 5.63 \\
\hline Lack of idea & 4.84 & 2.74 & 10.95 & 25.65 & 76.74 & 1.41 \\
\hline $\begin{array}{l}\text { Satisfaction with the current pro- } \\
\text { fessional situation }\end{array}$ & 6.45 & 2.74 & 3.65 & 19.37 & 0.00 & 7.04 \\
\hline I do not know & 17.74 & 2.74 & 4.01 & 5.76 & 0.00 & 8.45 \\
\hline \multicolumn{7}{|c|}{ Foreign students } \\
\hline Lack of financial resources & 46.67 & 50.00 & 61.04 & 33.33 & 0.00 & 14.29 \\
\hline Insufficient Knowledge & 31.67 & 25.53 & 22.08 & 19.05 & 0.00 & 19.05 \\
\hline Fear of risk & 5.00 & 8.51 & 9.09 & 9.25 & $100.00 *$ & 14.29 \\
\hline No consent from family members & 0.00 & 1.06 & 1.30 & 0.00 & 0.00 & 0.00 \\
\hline Lack of idea & 5.00 & 11.70 & 12.19 & 14.29 & 0.00 & 19.05 \\
\hline $\begin{array}{l}\text { Satisfaction with the current pro- } \\
\text { fessional situation }\end{array}$ & 1.67 & 1.06 & 1.30 & 0.00 & 0.00 & 4.76 \\
\hline I do not know & 10.00 & 2.13 & 1.30 & 19.05 & 0.00 & 28.57 \\
\hline
\end{tabular}

Only one respondent answered "definitely no". This figure, therefore, cannot be interpreted Source: own study. 
The lack of consent of family members to start a business and satisfaction with the current professional situation turned out to be the barriers of the least importance. However, a higher frequency of intentions for the second of these reasons was noticeable in the group of Polish respondents. Respondents asked about readiness to start a business in the scenario of receiving financial support, gave similar answers regardless of their nationality (Figure 1). About $20 \%$ of respondents from each of the surveyed groups would then decide to start a business. The percentage of people answering' rather not' or 'definitely not' together was higher on the Poles' side $-21.31 \%$, while among foreigners it was $16.28 \%$. There were more there was more hesitancy on the part of foreign respondents - however, it should be remembered that this group was more likely to plan to launch a business despite the lack of sufficient financial resources. In addition, they more often indicated the lack of ideas as the main barrier to starting business than the lack of financial resources.

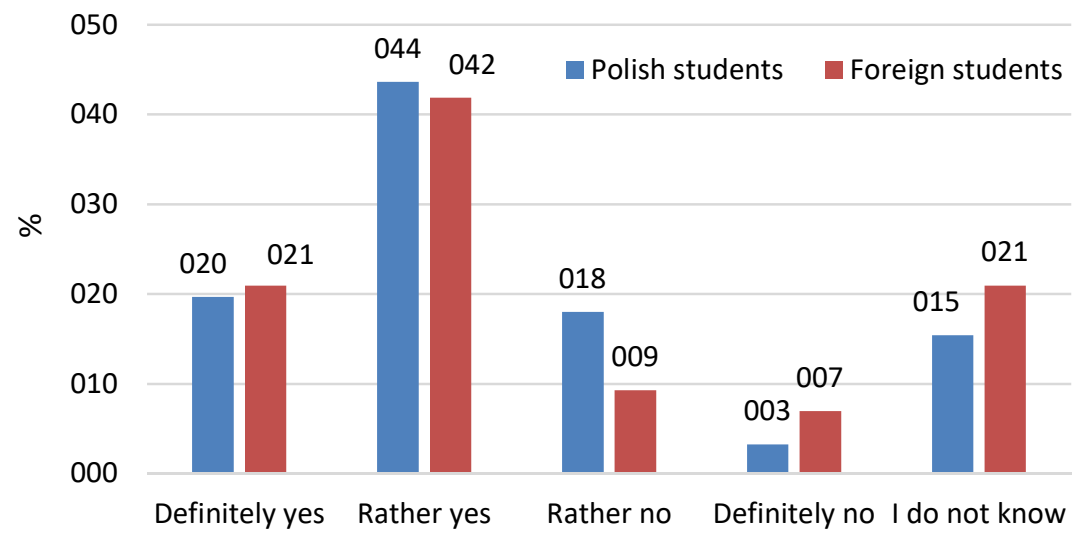

Figure 1. Attitude to starting a business in the case of obtaining a sufficient pool of financial resources among respondents who have not yet planned to start a business (previous answers were definitely no, rather no or I do not know) Source: own elaboration.

\section{Educational needs of foreign students and Polish students in the light of plans related to starting a business}

The feeling among respondents of not having enough knowledge to start a business, which appears quite often leads to recognizing the educational needs of students, depending on their plans related to the direction of taking up economic activity in the future. Throughout research on this issue, respondents were asked to indicate what types of issues related to running a business form part to their interests (Table 4). The structure of the answers provided varied slightly depending on the readiness to start a business, as well as depending on whether the respondents already had experience in conducting one. The topics related to marketing and promotion of the company, as well as grants for financing activities, were particularly popular among Polish students. Over $50 \%$ of surveyed students showed interest in marketing and company promotion issues. For the remaining groups of respondents separated due to their attitude to starting a business, these issues were also important, while the structure of responses was already less polarized. The topic of computer courses garnered the least interest. The group most strongly interested in the basics of accounting 
Table 4. Educational needs in setting up a business - the percentage of responses in groups of respondents with different intentions regarding running a business (multiple choice question)

\begin{tabular}{|l|c|c|c|c|c|c|c|r|r|}
\hline \multirow{2}{*}{$\begin{array}{c}\text { Educational needs - possible re- } \\
\text { sponses }\end{array}$} & \multicolumn{7}{|c|}{ Intention to start a business-percentage of } \\
responses [\%] & \multicolumn{2}{c|}{$\begin{array}{c}\text { Experience in run- } \\
\text { ning a business }\end{array}$} \\
\cline { 2 - 10 } & A & B & C & D & E & F & Yes & No \\
\hline \multicolumn{7}{|c|}{ Polish students } \\
\hline $\begin{array}{l}\text { Administrative and legal aspects } \\
\text { of starting a business }\end{array}$ & 32.26 & 39.73 & 36.13 & 32.46 & 30.23 & 32.39 & 36.99 & 34.17 \\
\hline Subsidies for business financing & 46.77 & 61.64 & 49.64 & 37.17 & 20.93 & 46.48 & 45.21 & 45.24 \\
\hline Marketing and promotion & 51.61 & 58.90 & 52.55 & 45.03 & 16.28 & 49.30 & 35.62 & 50.08 \\
\hline Writing business plans & 19.35 & 36.99 & 34.67 & 21.47 & 27.91 & 23.94 & 24.66 & 29.02 \\
\hline Basics of accounting & 17.74 & 26.03 & 31.02 & 32.46 & 32.56 & 32.39 & 23.29 & 30.73 \\
\hline Computer training & 9.68 & 8.22 & 13.87 & 18.32 & 13.95 & 22.54 & 10.96 & 15.44 \\
\hline Activation and creativity training & 29.03 & 15.07 & 17.15 & 23.56 & 16.28 & 12.68 & 24.66 & 18.56 \\
\hline $\begin{array}{l}\text { Time management and organiza- } \\
\text { tion of own work }\end{array}$ & 38.71 & 32.88 & 27.37 & 30.37 & 30.23 & 22.54 & 27.40 & 29.64 \\
\hline Human resource management & 33.87 & 30.14 & 30.29 & 36.65 & 34.88 & 32.40 & 35.62 & 32.45 \\
\hline \multicolumn{7}{|c|}{ Foreign } & students & & \\
\hline $\begin{array}{l}\text { Administrative and legal aspects } \\
\text { of starting a business }\end{array}$ & 40.00 & 34.04 & 24.68 & 19.95 & 0.00 & 14.29 & 35.00 & 28.50 \\
\hline Subsidies for business financing & 25.00 & 21.78 & 15.58 & 9.52 & $100.0 *$ & 9.52 & 26.67 & 16.82 \\
\hline Marketing and promotion & 66.67 & 70.21 & 63.64 & 61.90 & 0.00 & 66.67 & 61.67 & 67.76 \\
\hline Writing business plans & 45.00 & 29.78 & 24.68 & 33.33 & 0.00 & 33.33 & 33.33 & 31.78 \\
\hline Basics of accounting & 11.67 & 14.89 & 10.39 & 19.05 & 0.00 & 4.76 & 10.00 & 13.08 \\
\hline Computer training & 10.00 & 11.70 & 22.08 & 19.05 & 0.00 & 42.86 & 18.33 & 16.82 \\
\hline Activation and creativity training & 20.00 & 35.11 & 29.87 & 28.57 & 0.00 & 42.86 & 30.00 & 30.37 \\
\hline $\begin{array}{l}\text { Time management and organiza- } \\
\text { tion of own work }\end{array}$ & 43.33 & 40.43 & 54.55 & 52.38 & 0.00 & 38.10 & 36.67 & 48.13 \\
\hline Human resource management & 46.67 & 54.26 & 36.36 & 66.67 & $100.0 *$ & 33.33 & 48.33 & 46.73 \\
\hline
\end{tabular}

* Only one respondent answered "definitely not". This figure, therefore, cannot be interpreted. A - Definitely yes; B - Rather yes; C - Considering; D - Rather no; E - Definitely no; F-I do not know Source: own study.

turned out to be respondents definitely not planning to conduct business activity, human resources management 'rather' not planning, and administrative and legal issues and writing business plans were indicated comparatively often in all groups. Compared to the group of respondents of Polish origin, foreigners felt the need for further training in the field of business subsidies to a much lesser extent. Their main focus turned out to be issues related to marketing and promotion of the company and this issue aroused significantly more interest in this group. The administrative and legal issues of starting a business and writing of business plans skills were most interested in the groups of respondents deciding to run a business. In fact, the percentage of those interested in this type of knowledge increased with the transition to a group with an increasingly strong determination to conduct business - from the percentage of responses at the level of $14.29 \%$ to $40.00 \%$ in the case of administrative and legal matters. Computer training and activation training as well as creativity training turned out to be the most needed from the point of view of people who do not express a position on possible business activity. International students more 
appreciated the usefulness of knowledge related to human resource management and time management, as well as the organization of their own work - especially those students who are not planning to undertake business activity.

It can be said that Polish respondents were more interested in knowledge directly related to launching and developing business activity, while those from abroad also had issues related to the long-term functioning of the enterprise and organizational matters of a more general nature. Regarding the relationship between experience in doing business and demand for knowledge, there were no significant differences for Polish respondents. People with no experience more perceived the need to acquire knowledge in the field of marketing and promotion of the company and in the field of accounting than those with prior experienced. On the side of foreign students, experience in running a business fostered the emergence of the need to supplement knowledge in the field of business subsidies. Slightly less so was the need to become familiar with marketing issues and others related to time management and work organization (less by 11.44 percentage points) than among people without experience. Experienced people more appreciated knowledge in the field of human resource management while the difference remained minimal (both among Poles and foreign students). Experience resulted in a stronger interest in administrative and legal matters - however, it grew more intensively among foreign students than among Polish students.

The conclusions presented were confirmed by the chi square test of independence (Table 5). Using this method, the relationship between the propensity to take up business activity and factors considered to be potentially determinative was investigated.

Table 5. Chi square test of independence results

\begin{tabular}{|l|l|r|r|}
\hline \multicolumn{2}{|c|}{ Willingness to run own business after graduation } & \multicolumn{1}{c|}{$\chi^{2}$} & Cramér's V \\
\hline \multicolumn{1}{|c|}{ Criterion } & \multicolumn{1}{c|}{ Nationality } & $149.70^{*}$ & 0.39 \\
\hline \multirow{2}{*}{ Gender (Woman; Man) } & Polish students & $24.78 *$ & 0.19 \\
\cline { 2 - 4 } & Foreign students & 8.85 & 0.18 \\
\hline \multirow{2}{*}{ Age (less than 23; 23 and more) } & Polish students & 5.75 & 0.09 \\
\cline { 2 - 4 } & Foreign students & 3.06 & 0.11 \\
\hline \multirow{2}{*}{ Study mode (full-time studies; part-time studies) } & Polish students & $17.99 *$ & 0.16 \\
\cline { 2 - 4 } & Foreign students & 3.39 & 0.11 \\
\hline \multirow{2}{*}{ Study cycle (I; II) } & Polish students & 1.89 & 0.05 \\
\cline { 2 - 4 } & Foreign students & 1.90 & 0.08 \\
\hline \multirow{2}{*}{ Receiving financial support (yes; no) } & Polish students & $112.57 *$ & 0.40 \\
\cline { 2 - 4 } & Foreign students & $45.29 *$ & 0.41 \\
\hline \multirow{2}{*}{ Having funds to start the business (yes; no) } & Polish students & $73.29 *$ & 0.32 \\
\cline { 2 - 4 } & Foreign students & $34.07 *$ & 0.35 \\
\hline \multirow{2}{*}{ Own experience in running a business (yes; no) } & Polish students & $116.47 *$ & 0.40 \\
\cline { 2 - 4 } & Foreign students & $25.88 *$ & 0.31 \\
\hline \multirow{2}{*}{ Family experience in running a business (yes; no) } & Polish students & $19.70 *$ & 0.17 \\
\cline { 2 - 4 } & Foreign students & $20.16 *$ & 0.27 \\
\hline
\end{tabular}

* Statistically significant $\alpha=0.05$

Source: own study.

It can be concluded that nationality significantly affects the readiness to conduct business after graduation. Both in the group of students from abroad and Poles, this readiness depended on such features as: the possibility of receiving support, funds, and the activities 
conducted by themselves or their relatives. Among Polish students, the declaration of willingness to start their own business depended additionally on a demographic factor such as gender, as well as the mode of study undertaken. In the case of a group of foreign students, the impact of such factors - which may indirectly affect the shaping of entrepreneurial attitudes - did not occur. This confirms the belief that there are more defined aspirations related to running own enterprises among students from abroad.

\section{CONCLUSIONS}

The conducted research allows concluding that the first hypothesis has been positively verified. There was a significant relationship between the nationality of the student groups surveyed and their level of specification of plans for starting a business. Moreover, research proves different attitudes towards entrepreneurship among immigrants and native-born citizens (Lee \& Eesley, 2018; B. Sundararajan \& M. Sundararajan, 2015,). Foreign students more strongly declared their willingness to lead their own enterprise. It also confirms the conclusions from the literature about the greater risk appetite of young people deciding to emigrate, which also translates into their plans related to economic activity.

The results of the conducted research also allow for positive verification of the second hypothesis. A manifestation of greater risk appetite was, among others, the attitude of foreign students to plan to lead their own enterprise in the face of a shortage of funds. The lack of financial resources often delaying the implementation of business plans by immigrant students, reported in other research (Mukta, 2015) was not a deterrent. At the same time, greater interest in subsidies for financing business activities among Polish students, with greater indecision in the implementation of economic plans and the more often declared lack of ideas for the profile of business activity may suggest that the current shape of financial and educational support systems is conducive to consolidating a certain pattern of behavior related to undertaking business activities that slightly limit the creativity of potential entrepreneurs or build their passive attitude. Therefore, from the point of view of building an educational offer, it may be first of all, inclination not only to transfer knowledge, which can be simultaneously obtained from other sources, but aimed at creating skills to use information, assess risk and gain soft skills. In other research it was also discovered that modern curricula do not develop entrepreneurship. (Fasla, 2017; Manero \& Edigo, 2014), Nevertheless it should be their main aim. (Lubis, 2014).

The most frequently indicated educational needs turned out not to be those closely related to the process of functioning of the enterprise, such as the basics of accounting, preparation of a business plan, but those related to the functioning of the enterprise in the external environment - administrative and legal aspects as well as marketing and public relations. On the other hand, the more frequently declared lack of knowledge on the part of foreign students with a greater propensity to take risks suggests the need to take special care of them in the form of transferring basic knowledge.

The Mazowieckie Voivodship is a region with high potential for entrepreneurship development, but also a place where competition is intensified and a constant influx of people is increasing. It may be interesting to answer the question about the shape of these phenomena in other regions of the country. For example, in voivodships with high entrepreneurship dynamics and a negative balance of international migration. The key question is also how immigrant students are able to cope with providing economic needs in such a 
dynamically developing region as the Mazowieckie Voivodship and the city of Warsaw. It is not known whether the described phenomenon will someday be a factor conducive to the growing disproportion between Mazowieckie and other voivodships. The special role of units educating immigrant students is to provide such skills that will stimulate their inclination to undertake economic activity support the economic development of the regions. Undoubtedly, this will affect the education system in the long run.

It is worth to underlining that the research findings cannot be generalized as it was conducted only among students from a particular university. It seems necessary to repeat the research on a larger and more diversified sample. It will allow making a comparable analysis and take into consideration the impact of cultural differences on entrepreneurial behaviors. Additional research should also allow recognizing students' needs and expectations. Another important aspect is to analyse institutional forms of support for entrepreneurship development.

\section{REFERENCES}

Andrejuk, K. (2016). Co skłania imigrantów do zakładania własnych firm? Analiza procesu samozatrudnienia i rozwijania przedsiębiorstw etnicznych na przykładzie społeczności Ukraińców w Polsce. Studia Migracyjne - Przeglqqd Polonijny, 3(161), 223-253.

Andrejuk, K., \& Korniychuk, A. (2018). Ukraińscy absolwenci polskich uczelni: przechodzenie ze studiów na rynek pracy w kontekście samozatrudnienia. Problemy Polityki Społecznej. Studia i Dyskusje, 40(1), 121-140.

Baltaci, A. (2017). A Comparison of Syrian Migrant Students in Turkey and Germany: Entrepreneurial Tendencies and Career Expectations. European Journal of Educational Research, 6(1), 1527. DOI: 10.12973/eu-jer.6.1.15.

Blume-Kohout, M. (2016). Why are some foreign-born workers more entrepreneurial than others?. The Journal of Technology Transfer, 41(6), 1327-1353. DOI: 10.1007/s10961-015-9438-3.

Brzozowski, J. (2017). Immigrant Entrepreneurship and Economic Adaptation: A Critical Analysis. Entrepreneurial Business and Economics Review, 5(2), 159-176. DOI: 10.15678/EBER.2017.050209.

Chen, W., Tajeddini, K., Ratten, V., \& Tabari, S. (2019). Educational immigrants: evidence from Chinese young entrepreneurs in the UK. Journal of Enterprising Communities: People and Places in the Global Economy, 13 (1/2), 196-215. DOI: 10.1108/JEC-11-2018-0093.

Coleman, D. (1992). Does Europe need immigrants? Population and work force projektions'. International Migration Review, 26(92), 412-461.

Cruickshank, P., \& Dupuis, A. (2015). The Adaptation of Intentional Immigrant Entrepreneurs: A Case Study. Entrepreneurial Business and Economics Review, 3(3), 77-93. DOI: 10.15678/EBER.2015.030305.

Fasla, N.P. (2017). A Study on entrepreneurship attitude among college students. International Journal of Research Science \& Management, 4(4), 53-59.

Glinka, B. (2018). Znaczenie badań przedsiębiorczości imigrantów dla nauk o zarzq̨dzaniu. Kolegium Zarządzania i Finansów, 161. Warszawa: Oficyna Wydawnicza SGH.

Główny Urząd Statystyczny (2019). Statistics Poland. Retrieved on October 10, 2019 from https://stat.gov.pl/en/databases

Iwu, Ch., Ezeuduji, I., Eresia-Eke, Ch., \& Tengeh, R. (2016). The Entrepreneurial Intention of University Students: The case of University of Technology In South Africa. Acta Universitatis Danubius. Economica, 12 (1), 164-181. 
Kahn, S., La Mattina, G., \& MacGarvie, M. (2017). "Misfits", "stars", and immigrant entrepreneurship. Small Business Economics, 49(3), 533-557.

Kaczmarczyk, P. (Ed.)(2013). Recent Trends in International Migration in Poland. The 2013 SOPEMI Report. CMR Working Papers 86/144. Centre of Migration Research.

Kerr, S.P., \& Kerr, W.R. (2016). Immigrant Entrepreneurship. Working Paper 17-011. Harvard Business School.

Kosała, M. (2016). Przedsiębiorczość imigrantów w państwach UE i krajach OECD. PrzedsiębiorczośćEdukacja, 12, 326-339.

Kubiciel-Lodzińska, S., Maj, J., \& Bębenek, P. (2018). Przedsiębiorczość imigrantów przewagq konkurencyjnq województwa opolskiego. Raport z badań. Opole: Opole University of Technology. DOI: 10.13140/RG.2.2.14151.96162.

Kuciński, K. (2004). Migracje w teorii ekonomii. International Journal of Management and Economics, 15, 10-20.

Kushnirovich, N., Heilbrunn, S., \& Davidovich, L. (2018). Diversity of Entrepreneurial perceptions: Immigrants vs. Native Population. European Management Review, 15(3), 341-355. DOI: 10.1111/emre.12105.

Lee, Y., \& Eesley, Ch. (2018). The persistence of entrepreneurship and innovative immigrants. Research Policy, 47(6), 1032-1044. DOI: 10.1016/j.respol.2018.03.007.

Li, Ch., Isidor, R., Dau, L., \& Kabst, R. (2018). The More the Merrier? Immigrant Share and Entrepreneurial Activities. Entrepreneurship Theory and Practice, 42(5), 698-733. DOI: 10.1111/etap.12277.

Lubis, R.L. (2014). Students' Entrepreneurial Strategy: Connecting Minds?. International Journal of Arts \& Sciences, 7(3), 545-568.

Majkut, R., Pluta, J., \& Rybczyński, R. (2016). A Socio-Economic Portrait of Foreign Students in Poland - as Exemplified by Students from Former CIS Studying at WSB University in Wroclaw. Management, 20 (2), 379-414. DOI: 10.1515/manment-2015-0071.

Manero, P.V., \& Egido, M.P. (2014). The Concept of entrepreneur in education: A pedagogical analysis. Procedia - Social and Behavioral Sciences, 139, 153-159. DOI: 10.1016/j.sbspro.2014.08.047.

Mukta, M. (2015). Entrepreneurship Education: A Students' Perspective. International Journal of EEntrepreneurship and Innovation, 5(1), 1-14. DOI: 10.4018/ijeei.2015010101.

Storen, L. (2004). Unemployment experiences during Elary Carter of immigrant and non-immigrant graduates. Journal of Education and Work, 17 (1), 71-93

Sundararajan, M., \& Sundararajan, B. (2015). Immigrant Capital and Entrepreneurial Opportunities. Entrepreneurial Business and Economics Review, 3(3), 29-50. doi: 10.15678/EBER.2015.030303.

Trzciński, R. (2015). Zagraniczni studenci - czy potencjalni uczestnicy polskiego rynku pracy? In J. Konieczna-Sałamatin (Ed.), Imigranci o wysokich kwalifikacjach na polskim rynku pracy. Raport z badań 2014-2015 (pp. 175-210). Warszawa: Instytut Społeczno-Ekonomicznych Ekspertyz Fundacja „Nasz Wybór”. 


\section{Authors}

The contribution of co-authors is as follows: Paulina Kramarz prepared the literature review, and data analysis (40\%), Maciej Dębski - data collection and literature review (30\%), Lidia Luty

- research methodology, statistical calculations and data analysis (30\%)

\section{Paulina Kramarz}

State Higher School of Vocational Education in Ciechanów. Master in Management and Marketing (University of Agriculture in Kraków); PhD in economics (Warsaw University of Life Sciences), Her research interests include: rural development economics, health economics, entrepreneurship in regional development.

Correspondence to: Paulina Kramarz, PhD, State Higher School of Vocational Education in Ciechanów, Narutowicza 9, 06-400 Ciechanów, Poland, e-mail: p-kramarz@wp.pl ORCID (1) http://orcid.org/0000-0002-6980-7158

\section{Maciej Dębski}

Master in Management and Master in International Relations (SGH Warsaw School of Economics) $\mathrm{PhD}$ in management (SGH Warsaw School of Economics). His research interests and practical aspects are focused on the use of marketing tools, especially in tourism. Professionally working at University of Social Sciences.

Correspondence to: Maciej Dębski, PhD, University of Social Sciences, Branch Campus in Warsaw, 11 Lucka St., 00-842 Warsaw, Poland, e-mail: mdebski@san.edu.pl ORCID (1) http://orcid.org/0000-0002-8339-5073

\section{Lidia Luty}

University of Agriculture in Kraków. Master in mathematics (Pedagogical University of Cracow), $\mathrm{PhD}$ in agricultural sciences. Habilitation degree in Economics (University of Szczecin). Her research interests include: application of quantitative methods in economics and management sciences, mathematics, regional development.

Correspondence to: Dr hab. Lidia Luty, University of Agriculture in Kraków. Al. Mickiewicza 21, 31-120 Kraków, Poland, e-mail: rrdutka@cyf-kr.edu.pl

ORCID (1) http://orcid.org/0000-0001-8250-8331

\section{Acknowledgements and Financial Disclosure}

The authors would like to thank the input of learned friends and colleagues whose contribution serves only to enhance the value of this research.

\section{Copyright and License}

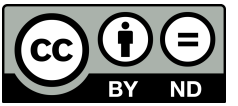

This article is published under the terms of the Creative Commons

Attribution - NoDerivs (CC BY-ND 4.0) License

http://creativecommons.org/licenses/by-nd/4.0/ 
